\title{
Association of serum uric acid and C-reactive protein levels in prediction of pre-eclampsia
}

\author{
Pawanpreet Kaur*, Deepak A. Desai, Aartee Taraiya, Apexa Patel
}

SBKS Medical Institute and Research Centre, Pipariya, Waghodia, Vadodara 391760, Gujarat, India

Received: 16 December 2015

Revised: 13 January 2016

Accepted: 16 January 2016

*Correspondence:

Dr. Pawanpreet Kaur,

E-mail: pavs_candy@yahoo.co.in

Copyright: (C) the author(s), publisher and licensee Medip Academy. This is an open-access article distributed under the terms of the Creative Commons Attribution Non-Commercial License, which permits unrestricted non-commercial use, distribution, and reproduction in any medium, provided the original work is properly cited.

\begin{abstract}
Background: Hypertensive disorders during pregnancy increase maternal and infant risk. The greatest impact is associated with the pregnancy-specific syndrome, preeclampsia, a consistently clinically worsening situation. PE is a complication of pregnancy, constituting a major cause of maternal and foetal morbidity, and mortality

Hyperuricemia and increased CRP level, in pre-eclamptic patients need to be confirmed, in a designed strategy, in which uric acid and CRP level are measured before the development of preeclampsia, or early in pregnancy, in order to identify and monitor the patients, "at risk of preeclampsia", and thus provide the best prenatal care for these women and their babies.

Methods: The study was done in Dhiraj Hospital in Obstetrics and Gynecology Department. The study duration was 1 year. It is a prospective type of study comprising of patients, who were attending ANC clinic and were booked cases at Dhiraj hospital. Serum uric acid and C-reactive protein were estimated along with other routine investigations for all patients attending ANC clinic. All the subjects were divided into two groups: (i) Group-1 (Study Group): Fifty diagnosed pre-eclamptic patients in third trimester of pregnancy (37-40 weeks) whose serum uric acid and CRP levels were already raised during her antenatal visits in second trimester, (ii) Group-2 (Control Group): fifty two normal pregnant women of comparable gestational age.

Results: The mean values of serum uric acid and CRP levels remain higher in study group than that of control group. This difference is statistically significant $(\mathrm{p}=0.02)$.

Conclusions: All the patients in study group whose measurement of uric acid and CRP levels were high, developed pre-eclampsia. So it can be fairly concluded, that the observed elevations in serum uric acid level or CRP level or both, preceded the development of pre-eclampsia.
\end{abstract}

Keywords: Pre-eclampsia, Serum uric acid levels, Serum CRP levels

\section{INTRODUCTION}

Hypertensive disorders during pregnancy increase maternal and infant risk. The greatest impact is associated with the pregnancy-specific syndrome, preeclampsia, and a consistently clinically worsening situation.
Preeclampsia (PE) develops in $4-5 \%$ of human pregnancies. It is characterized by an elevated blood pressure, more than $140 / 90 \mathrm{~mm}$ of $\mathrm{Hg}$, on two separate occasions, taken six hours apart, within a period of one week, and evidence of proteinuria, which develops after 20 weeks of gestation. PE is a complication of pregnancy, constituting a major cause of maternal and foetal morbidity, and mortality. Several aetiologies have been 
implicated in the development of preeclampsia, including abnormal trophoblast invasion of uterine blood vessels, and immunological intolerance between feto-placental and maternal tissues. Endothelial cell dysfunction and inflammation are considered to have a role in the pathophysiology of PE.

A generalized activation of circulating leukocytes, characteristic of inflammation, has been found during PE. Moreover, increased concentrations of CRP and inflammatory cytokines have been reported in PE women.

CRP is produced by the liver and the production is stimulated by the inflammatory cytokines, interleukin- 6 and TNF-alpha. CRP level increases during inflammatory response to tissue injury or infection. CRP, though not pathology specific, as it increases in a number of conditions, is an objective and sensitive index of overall inflammatory activity in the body. Plasma CRP levels rise in cases of acute infection, malignancy \& inflammatory diseases. It has been suggested that elevated levels of CRP, in accordance with its proposed function, may reflect the inflammatory response characteristics of preeclampsia.

Table 1: C-reactive protein (serum) - normal levels.

\begin{tabular}{|cllll|}
\hline Units & $\begin{array}{l}\text { Non- } \\
\text { pregnant } \\
\text { adult }\end{array}$ & $\begin{array}{l}\text { First } \\
\text { Trim- } \\
\text { ester }\end{array}$ & $\begin{array}{l}\text { Second } \\
\text { Trim- } \\
\text { ester }\end{array}$ & $\begin{array}{l}\text { Third } \\
\text { Trim- } \\
\text { ester }\end{array}$ \\
\hline mg/L & $0.2-3$ & $\begin{array}{l}\text { Not } \\
\text { reported }\end{array}$ & $0.4-20.3$ & $0.4-8$ \\
\hline
\end{tabular}

Raised serum uric acid (UA) is one of the characteristic findings in preeclampsia. In clinical practice, serum UA determination is considered to be a part of the workup, in women with preeclampsia, to monitor disease severity, and aid management, of these women.

Uric acid is a product of purine degradation, catalyzed by the enzyme xanthine dehydrogenase/xanthine oxidase (XDH/XO). $\mathrm{XDH}$ is converted to its oxidase form $\mathrm{XO}$, by several stimuli, including ischemia. ${ }^{1}$ Purine metabolism by $\mathrm{XO}$, couples the production of uric acid, with the production of the free radical superoxide (O2-), and, is implicated as a contributor to oxidative stress. ${ }^{1}$ $\mathrm{XDH} / \mathrm{XO}$ is found in most tissues, but is concentrated in the liver and gut. Recently, a circulating population of XO has been identified that increases dramatically, following ischemic tissue damage. ${ }^{2}$ Increased circulating uric acid accompanies similar insults. ${ }^{3}$ It is speculated that circulating XO can bind to endothelium and lead to local oxidative injury. ${ }^{4}$

Hyperuricemia is a common finding in pre-eclamptic pregnancies. The elevation of uric acid in pre-eclamptic women, often precedes hypertension and proteinuria, the clinical manifestations, used to diagnose the disorder. ${ }^{5}$ There are several potential origins, for uric acid in preeclampsia; abnormal renal function, increased tissue breakdown, acidosis and increased activity of the enzyme xanthine oxidase/dehydrogenase. ${ }^{6}$ However, despite hyper-uricemia antedating other clinical findings of preeclampsia, it has historically been ascribed to reflect impaired renal function. Reduced UA clearance, secondary to reduced glomerular filtration rate, increased reabsorption, and decreased secretion, may be at the origin of elevated serum levels in women with preeclampsia. It is one of the most consistent and earliest detectable changes, in preeclampsia and has been cited as a better predictor, of fetal risk, than blood pressure.

Uric acid is capable of damaging adult vasculature, and could have similar effects in the placentae of preeclamptic women. The placental vasculature lacks autonomic innervation, relying entirely upon locally produced or circulating substances, for hemodynamic control. ${ }^{7}$ The primary vasoactive compound responsible, for the maintenance of optimized placental perfusion, is endothelial derived NO. Uric acid decreases eNOS activity limiting NO availability, and up-regulates COX-2 expression, with increased generation, of the potent vasoconstrictor thromboxane. ${ }^{8}$ A similar vaso-constrictive effect of uric acid in the placentae of women with preeclampsia would compromise placental perfusion, and could inhibit fetal growth.

Table 2: Uric acid (serum) - normal levels.

\begin{tabular}{|llll|l|} 
Units & $\begin{array}{l}\text { Non- } \\
\text { pregnant } \\
\text { female }\end{array}$ & $\begin{array}{l}\text { First } \\
\text { Trim- } \\
\text { ester }\end{array}$ & $\begin{array}{l}\text { Second } \\
\text { Trim- } \\
\text { ester }\end{array}$ & $\begin{array}{l}\text { Third } \\
\text { Trim- } \\
\text { ester }\end{array}$ \\
\hline $\mathrm{mg} / \mathrm{dL}$ & $2.5-5.6$ & $2-4.2$ & $2.4-4.9$ & $3.1-6$ \\
\hline$\mu \mathrm{mol} / \mathrm{L}$ & $149-333$ & $119-250$ & $143-292$ & $184-375$ \\
\hline
\end{tabular}

Pre-eclampsia is a potential harmful situation during antenatal period that culminates in events increasing maternal and fetal morbidity and mortality.

In many instances, the situation defies the treatment once it is fully developed.

Early diagnosis or recognition of the onset of Preeclamptic changes can help curb and control the situation, limiting the undesirable results. For this purpose, detection of these two parameters, abnormal levels in early stage of developing Pre-eclampsia can certainly achieve the goal of safe motherhood and child survival.

\section{METHODS}

The study was done in Dhiraj Hospital in Obstetrics and Gynecology department. The study duration was 1 year. It is a prospective type of study comprising of patients, who were attending ANC clinic and were booked cases at Dhiraj hospital. 


\section{Aims of the study}

The study aimed,

1. To study the role of elevated levels of Uric acid and C-reactive protein in patients with preeclampsia.

2. For early screening of patients who are at risk of developing preeclampsia and eclampsia.

\section{Inclusion criteria}

1. All antenatal patients who are booked at Dhiraj hospital.

2. All antenatal patients who have singleton pregnancy.

\section{Exclusion criteria}

1. All antenatal patients who are known cases of chronic hypertension.

2. All antenatal patients who have renal or cardiac disorders.

3. All antenatal patients who have inflammatory conditions, respiratory tract infections.

4. All antenatal patients with multiple gestations.

All the cases and controls in the study were subjected to detailed history.

Systemic examination with special reference to oedema, blood pressure and gestational age was carried out.

Routine Antenatal Investigations were recorded in the proforma specially designed for the study. Serum uric acid levels and CRP levels were measured for all the patients attending the OPD and were followed up till delivery.

These available data was co-related as per further study design.

The diagnosis of preeclampsia was based on the definition of american college of obstetrics and gynecology:
I. Systolic blood pressure greater than $140 \mathrm{mmhg}$ or a rise of at least $30 \mathrm{Mmhg}$.

II. Diastolic blood pressure greater than $90 \mathrm{Mmhg}$ or A rise of at least $15 \mathrm{Mmhg}$ (Measured on two occasions at least 6 hours apart) and proteinuria of $300 \mathrm{Mg}$ or more in 24 hours urine collection or protein concentration of $1 \mathrm{Gm} / \mathrm{L}$ (on two occasions of at least 6 hours apart), or $\geq 2+$ in mild preeclampsia and $>3+$ in severe preeclampsia by dipstick method.

All the subjects were divided into two groups:

Group 1 (Study group):

Fifty diagnosed Pre-eclamptic patients in third trimester of pregnancy (37-40 weeks) whose serum uric acid and CRP levels were already raised during her antenatal visits in second trimester.

\section{Group 2 (Control group):}

Fifty two normal pregnant women of comparable gestational age.

\section{Statistical methods}

Data will be analysed and appropriate statistical methods like chi-square test, population test or T-test, Pearson's formula will be employed to analyse data throughout study.

\section{RESULTS}

Table 3: Distribution according to age group.

\begin{tabular}{|lll|}
\hline Age (years) & Study group & Control group \\
\hline $18-25$ & & \\
\hline $26-30$ & $18(36 \%)$ & $18(36 \%)$ \\
\hline $31-35$ & $20(40 \%)$ & $5(10 \%)$ \\
\hline Total & 50 & 50 \\
\hline
\end{tabular}

Table 4: Comparison of mean \pm Sd of blood pressure ( $\mathrm{mmHg}$ ) level between the study group and control group.

\begin{tabular}{|lllllll|l|}
\hline Parameter $(\mathrm{mmHg})$ & \multirow{2}{*}{ No. of patients } & \multicolumn{2}{c|}{ Study Group } & \multicolumn{2}{c|}{ Control Group } & t-test & P value \\
\hline Systolic blood pressure & 50 & Mean & SD & Mean & SD & & \\
\hline Diastolic pressure & 50 & 150.8 & 8.6 & 114.3 & 8.6 & 21.24 & 0.0001 \\
\hline
\end{tabular}

The comparison of mean $\pm \mathrm{SD}(\mathrm{mmHg})$ of blood pressure between the study groups and controls. It is seen that the mean \pm SD of systolic as well as diastolic blood pressure levels in pre-eclamptic women $(150.8 \pm 8.6 \mathrm{mmHg}, 101.3$ $\pm 8.01 \mathrm{mmHg}$ ) are much higher than that of normal pregnant women $(114.3 \pm 8.6 \mathrm{mmHg}, 74.4 \pm 6.9 \mathrm{mmHg})$.
This difference is found to be very highly significant $(\mathrm{P}=0.0001)$.

CRP level is within moderate increase range in $46 \%$ patients of study group and $43 \%$ patients of control group. It is above the upper limit of normal range (i.e. >8 
$\mathrm{mg} / \mathrm{L})$ in $54 \%$ patients of study group and $8 \%$ patients of control group. The data is statistically significant $(\mathrm{P}=0.0001)$.

Table 5: CRP levels in study group and control group.

\begin{tabular}{|llllll|}
\hline $\begin{array}{l}\text { CRP } \\
(\mathrm{mg} / \mathrm{L})\end{array}$ & $\begin{array}{l}\text { Study } \\
\text { group } \\
\text { no. }(\%)\end{array}$ & $\begin{array}{l}\text { Control } \\
\text { group } \\
\text { no. } \%)\end{array}$ & $\begin{array}{l}\text { Chi } \\
\text { Square }\end{array}$ & Dof & $\begin{array}{l}\text { P } \\
\text { value }\end{array}$ \\
\hline $0.4-8$ & $\begin{array}{l}23 \\
(46 \%)\end{array}$ & $\begin{array}{l}43 \\
(86 \%)\end{array}$ & 16.36 & 2 & 0.0001 \\
\hline$>8$ & $\begin{array}{l}27 \\
(54 \%)\end{array}$ & $\begin{array}{l}8 \\
(16 \%)\end{array}$ & & & \\
\hline
\end{tabular}

Table 6: Uric acid levels in study group and control group.

\begin{tabular}{|llllll|}
\hline $\begin{array}{l}\text { Uric } \\
\text { acid } \\
(\text { mg \%) }\end{array}$ & $\begin{array}{l}\text { Study } \\
\text { group } \\
\text { no. }(\%)\end{array}$ & $\begin{array}{l}\text { Control } \\
\text { group } \\
\text { no. }(\%)\end{array}$ & $\begin{array}{l}\text { Chi } \\
\text { Square }\end{array}$ & Dof & $\begin{array}{l}\text { P } \\
\text { value }\end{array}$ \\
\hline$<3$ & 0 & $8(16 \%)$ & 28.55 & 2 & 0.0001 \\
\hline 3 to 6 & $\begin{array}{l}29 \\
(58 \%)\end{array}$ & $\begin{array}{l}42 \\
(84 \%)\end{array}$ & & & \\
\hline$>6$ & $\begin{array}{l}21 \\
(42 \%)\end{array}$ & $1(2 \%)$ & & & \\
\hline
\end{tabular}

It is observed that uric acid level is within moderate increase range in $58 \%$ of study group (pre-eclamptic group) and $84 \%$ patients of control group, whereas it is above the upper limit of normal range (i.e. $>6 \mathrm{mg} \%$ ) in $42 \%$ of study group and $2 \%$ patients in control group.

The data is statistically significant $(\mathrm{P}=0.0001)$.

Table 7: Relationship /comparison between mean value of serum uric acid level and CRP level in study group and control group.

\begin{tabular}{|lllllll|}
\hline $\begin{array}{l}\text { Para- } \\
\text { meters }\end{array}$ & Group & $\begin{array}{l}\text { Mean } \\
\pm \text { SD }\end{array}$ & $\begin{array}{l}\text { Med- } \\
\text { ian }\end{array}$ & $\begin{array}{l}\mathrm{t} \\
\text { test }\end{array}$ & Dof & $\begin{array}{l}\mathrm{p} \\
\text { value }\end{array}$ \\
\hline CRP & Study & $\begin{array}{l}6.8 \pm \\
3.4\end{array}$ & 8.4 & 2.33 & 99 & 0.02 \\
& $\begin{array}{l}\text { Cont- } \\
\text { rol }\end{array}$ & $\begin{array}{l}5.4 \pm \\
2.8\end{array}$ & 5.4 & & & \\
\hline $\begin{array}{l}\text { Uric } \\
\text { acid }\end{array}$ & Study & $\begin{array}{l}5.8 \pm \\
1.8\end{array}$ & 5.4 & 5.88 & 99 & $\begin{array}{l}0.000 \\
1\end{array}$ \\
\hline & $\begin{array}{l}\text { Cont- } \\
\text { rol }\end{array}$ & $\begin{array}{l}4.1 \pm \\
1.05\end{array}$ & 4.2 & & & \\
\hline
\end{tabular}

It is observed that mean value of serum uric acid level in study group is $5.8 \pm 1.8 \mathrm{mg} \%$ which is quite higher than that of control group i.e. $4.1 \pm 1.05 \mathrm{mg} \%$ and this difference is statistically significant $(\mathrm{p}=0.0001)$. On the other, the mean value of serum CRP level in study group is higher $(6.8 \pm 3.4 \mathrm{mg} / \mathrm{L})$ than that of control group $(5.4 \pm 2.8 \mathrm{mg} / \mathrm{L})$, this difference is statistically significant $(\mathrm{p}=0.02)$. The mean values of serum uric acid and CRP levels remain higher in study group than that of control group.
In control group, the rise in CRP levels and Uric acid levels remain less in comparison of the study group (Table 7), and there was no rise in blood pressure. The mean values of serum uric acid and CRP levels remain higher in study group than that of control group. There is a strong association of increased levels of uric acid and CRP, with level of increase in blood pressure (Table 8).

Table 8: Co-relation matrix of serum uric acid level, blood pressure and CRP level.

\begin{tabular}{|lllll|}
\hline & Uric Acid & SBP & DBP & CRP \\
\hline Uric Acid & 1 & $0.51^{*}$ & $0.4^{*}$ & $0.56^{*}$ \\
\hline SBP & $0.51^{*}$ & 1 & $0.61^{*}$ & $0.37^{*}$ \\
\hline DBP & $0.4^{*}$ & $0.61^{*}$ & 1 & $0.13^{*}$ \\
\hline CRP & $0.56^{*}$ & $0.37^{*}$ & $0.13^{*}$ & 1 \\
\hline
\end{tabular}

*Correlation is significant at the 0.01 level.

In order to study the correlation among the parameters viz. serum uric acid, blood pressure and serum CRP Pearson's correlation coefficient " $\mathrm{r}$ " is advocated and findings are shown in Table 8 .

$$
r_{x y}=\frac{\sum_{i=1}^{n}\left(x_{i}-\bar{x}\right)\left(y_{i}-\bar{y}\right)}{\sqrt{\sum_{i=1}^{n}\left(x_{i}-\bar{x}\right)^{2} \sum_{i=1}^{n}\left(y_{i}-\bar{y}\right)^{2}}}
$$

The analysis is based on the study group only. Depending on this formula, it is highlighted, that there is a strong positive correlation between serum uric acid and blood pressure (systolic and diastolic) which is highly significant. A significant positive correlation is also observed between serum uric acid and serum CRP level.

Table 9: Mode of delivery.

\begin{tabular}{|l|l|l|}
\hline $\begin{array}{l}\text { Mode of } \\
\text { delivery }\end{array}$ & $\begin{array}{l}\text { Study group } \\
(\mathbf{n = 5 0}) \mathbf{N o}(\%)\end{array}$ & $\begin{array}{l}\text { Control group } \\
(\mathbf{n}=50) \text { No. }(\%)\end{array}$ \\
\hline $\begin{array}{l}\text { Normal vaginal } \\
\text { delivery }\end{array}$ & $35(70 \%)$ & $42(84 \%)$ \\
\hline LSCS & $10(20 \%)$ & $6(12 \%)$ \\
\hline $\begin{array}{l}\text { Instrumental } \\
\text { delivery } \\
\text { (forceps) }\end{array}$ & $5(10 \%)$ & $2(4 \%)$ \\
\hline
\end{tabular}

In study group, $35(70 \%)$ cases had normal vaginal delivery.

$10(20 \%)$ had LSCS; 2 for foetal distress, 2 for thick meconium, 4 for thin meconium, 2 for Cephalo- Pelvic Disproportion.

In control group, $42(84 \%)$ cases had normal vaginal delivery.

6 (12\%) had LSCS; 1 for thick meconium; 4 for foetal distress; 1 for Cephalo-pelvic disproportion. 
Outlet forceps deliveries were to cut down the duration of second stage, $\&$ there by reducing the time of exposure to detrimental situation, as cervix was fully dilated in these cases.

Table 10: Birth weights.

\begin{tabular}{|lll|}
\hline $\begin{array}{l}\text { Weight } \\
\text { (kgs) }\end{array}$ & $\begin{array}{l}\text { Study group } \\
\text { No. }(\%)\end{array}$ & $\begin{array}{l}\text { Control group } \\
\text { No. }(\%)\end{array}$ \\
\hline $1.5-2 \mathrm{~kg}$ & $4(8 \%)$ & 0 \\
\hline $2.1-2.5 \mathrm{~kg}$ & $36(72 \%)$ & $30(60 \%)$ \\
\hline $2.6-3 \mathrm{~kg}$ & $10(20 \%)$ & $20(40 \%)$ \\
\hline
\end{tabular}

Chi-square is $7.87(\mathrm{p}=0.019)$

The mean birth weight was $2.3 \mathrm{Kg}$ in study group and 2.5 $\mathrm{Kg}$ in control group. The occurrence of birth weight $\leq 2.5$ $\mathrm{Kg}$ was seen in $40(80 \%)$ and $30(60 \%)$ in study group and control group respectively. The occurrence of low birth weight $(\leq 2.5 \mathrm{Kg})$, the difference was statistically significant $(\mathrm{p}<0.05)$.

Table 11: Admission to neonatal intensive care unit.

\begin{tabular}{|ll|}
\hline $\begin{array}{l}\text { Study group }(\mathrm{n}=50) \\
\text { No. }(\%)\end{array}$ & $\begin{array}{l}\text { Control group }(\mathrm{n}=50) \\
\text { No. }(\%)\end{array}$ \\
\hline $10(20 \%)$ & $2 \quad(4 \%)$ \\
\hline
\end{tabular}

Chi-square is 6.06. $(\mathrm{p}=0.013)$

In study group, 10 (20\%) neonates of study group were admitted to neonatal intensive care unit for various morbidities like birth asphyxia, meconium aspiration, intrauterine growth retardation, transient tachypnoea of newborn. Only 2 (4\%) of control group were admitted to neonatal intensive care unit. The difference in the two groups was statistically significant $(\mathrm{P}<0.05)$.

Table 12: Neonatal deaths.

\begin{tabular}{|ll|}
\hline Study group $(n=50)$ & Control group $(n=50)$ \\
No. $(\%)$ & No. $(\%)$ \\
\hline $3(6 \%)$ & $1(2 \%)$ \\
\hline
\end{tabular}

Chi- square is 1.04. $(\mathrm{p}=0.30)$

There were 3 early neonatal deaths in study group and 1 early neonatal death in control group. The difference in the neonatal deaths was statistically non-significant between two groups $(\mathrm{P}=0.30)$. In study group, 1 neonate who died, the mode of delivery was LSCS and 2 neonates who died, delivered vaginally. In control group, there was 1 neonatal death and the mode of delivery was LSCS.

The reasons of deaths were following:

\section{In study group:}

- One neonate died due to Meconium Aspiration Syndrome.

- Two died due to IUGR with early onset of sepsis.
The mothers of these three neonates had severe preeclampsia with serum uric acid and CRP levels greater than the upper limit of normal range. (CRP $>8 \mathrm{mg} / \mathrm{L}$ and uric acid $>6 \mathrm{mg} \%$ ).

\section{In control group:}

- One neonatal death was due to meconium aspiration syndrome with severe birth asphyxia.

Table 13: Perinatal outcome.

\begin{tabular}{|lll|}
\hline Parameter & $\begin{array}{l}\text { Study group } \\
(\mathrm{n}=50)\end{array}$ & $\begin{array}{l}\text { Neonatal } \\
\text { morbidity no. }(\%)\end{array}$ \\
\hline $\begin{array}{l}\mathrm{CRP}>8 \mathrm{mg} / \mathrm{L} \\
\text { and }\end{array}$ & $7(33.3 \%)$ \\
$\begin{array}{l}\text { Uric acid }>6 \\
\mathrm{mg} \%\end{array}$ & 21 & \\
\hline $\begin{array}{l}\mathrm{CRP}-0.4 \text { to } 7.9 \\
\mathrm{mg} / \mathrm{L} \text { and }\end{array}$ & $2(6.8 \%)$ \\
$\begin{array}{l}\text { Uric acid }-3 \text { to } \\
5.9 \mathrm{mg} \%\end{array}$ & 29 & \\
\hline
\end{tabular}

In study group, there are 21 patients whose CRP and uric acid levels were above the upper limit of the normal range (CRP $>8 \mathrm{mg} / \mathrm{L}$ and uric acid $>6 \mathrm{mg} \%$ ) at around 30 to 34 weeks of gestation. These patients had progressed to severe pre-eclampsia. Their blood pressure was controlled with two hypertensive drugs; tablet Labetalol (100mg) B.D. and Tablet Methyl Dopa (250 mg) T.I.D.

After delivery of these 21 patients (mothers), 7 neonates were admitted to neonatal intensive care unit.

- Three neonates had IUGR and were admitted for two weeks, for adequate weight again and antibiotic therapy. But two of these neonates died due to early onset of sepsis and one was returned to mother after 2 weeks.

- Two had moderate birth asphyxia, and were kept on ventilator for 12 hours followed by oxygen administration for 12-24 hours with antibiotic therapy. These neonates were returned to mother within 24-48 hours.

- Three neonates had meconium aspiration syndrome. They were given gastric lavage and were on ventilator. One neonate died, within 12 hours of birth. The other two were stepped down to oxygen for next 24 hours along with antibiotic therapy. These neonates were returned to mother within 4872 hours.

In rest of 29 patients, there were moderate increase CRP and uric acid levels (CRP - 0.4 to $7.9 \mathrm{mg} / \mathrm{L}$ and uric acid 3 to $5.9 \mathrm{mg} \%$ ) at around $30-34$ weeks of gestations. These patients had developed mild pre-eclampsia. Their blood pressure was controlled by a single antihypertensive drug; Tablet Labetalol (100 mg) B.D. 
After delivery of these 29 patients (mothers), 2 neonates were admitted to neonatal intensive care unit.

- One neonate had meconium aspiration syndrome and was given gastric lavage and was kept on CPAP for 24 hours followed by oxygen by hood for next 12 hours along with antibiotic therapy. The neonate was returned to mother within 48 hours.

- The other one had IUGR and was admitted for two weeks, for adequate weight gain and antibiotic therapy. The neonate was returned to mother after two weeks.

In control group, only 2 neonatal admissions were there in intensive care unit.

- One neonate for transient tachypnoea of newborn was administered oxygen for 12 hours and was returned to mother within 24 hours.

- The other neonate had meconium aspiration syndrome with birth asphyxia and was kept on ventilator but could not survive and died within 6 hours of birth. The patient (mother) had higher levels of CRP and uric acid above the upper limit, but not associated with elevated blood pressure. Also, the gestation age of the patient (mother) was 40 weeks, so meconium leakage was possibly due to intrapartum placental dysfunction.

There was No maternal morbidity or mortality in our study.

\section{DISCUSSION}

The mean \pm SD of blood pressure $(\mathrm{mmHg})$ was significantly higher in preeclampsia $(150.8 \pm 8.6 \mathrm{mmHg}$, $101.3 \pm 8.01 \mathrm{mmHg}$ ) compared with normal controls (systolic: $114.3 \pm 8.6 \mathrm{mmHg}$, diastolic: $74.4 \pm 6.9$ $\mathrm{mmHg}$ ).

The level of serum uric acid was significantly higher in the study group than in the controls $(5.8 \pm 1.8 \mathrm{mg} / \mathrm{dl}$ versus $4.1 \pm 1.05 \mathrm{mg} / \mathrm{dl})$. In study group, $21 \%$ women have uric acid level more than upper limit of normal range $(>6 \mathrm{mg}$ $\%)$. The data is statistically very significant $(\mathrm{P}=0.0001)$.

Elevated serum uric acid levels due to decreased renal urate excretion are frequently found in women with preeclampsia. ${ }^{9}$ Soluble uric acid impairs nitric oxide generation in endothelial cells inducing endothelial dysfunction. ${ }^{10}$ Besides the reduced clearance hyperuricemia in pre-eclampsia may be due to increased uric acid production caused by trophoblast breakdown, cytokine release and ischemia. Uric acid can promote endothelial dysfunction, damage and inflammation, which leads to oxidation. So, preeclampsia, which is characterized by widespread endothelial dysfunction and inflammation, might be propagated by uric acid. ${ }^{11}$ It has also been reported that rise in uric acid level in preeclampsia is secondary to placental damage leading to purine catabolism and production of uric acid.

The human placenta receives its blood supply from numerous uteroplacental arteries that are developed by the action of migratory interstitial and endovascular trophoblast into the walls of the spiral arterioles. This transforms the uteroplacental arterial bed into a lowresistance, low-pressure, high-flow system. The conversion of the spiral arterioles of the non pregnant uterus into the uteroplacental arteries has been termed physiologic changes. ${ }^{12}$ In a normal pregnancy, these trophoblast-induced vascular changes extend all the way from the intervillous space to the origin of the spiral arterioles from the radial arteries in the inner one third of the myometrium. It is suggested that these vascular changes are effected in two stages: "the conversion of the decidual segments of the spiral arterioles by a wave of endovascular trophoblast migration in the first trimester and the myometrial segments by a subsequent wave in the second trimester". 12 This process is reportedly associated with extensive fibrinoid formation and degeneration of the muscular layer in the arterial wall. These vascular changes result in the conversion of approximately 100 to 150 spiral arterioles into distended, tortuous, and funnel-shaped vessels that communicate through multiple openings into the intervillous space.

In contrast, pregnancies complicated by preeclampsia demonstrate inadequate maternal vascular response to placentation. In these pregnancies, the above-mentioned vascular changes are usually found only in the decidual segments of the uteroplacental arteries. Hence, the myometrial segments of the spiral arterioles are left with their musculo-elastic architecture, thereby leaving them responsive to hormonal influences. ${ }^{12}$ Additionally, the number of well-developed arterioles is smaller than that found in normotensive pregnancies. Kong and colleagues have postulated that this defective vascular response to placentation is due to inhibition of the second wave of endovascular trophoblast migration that normally occurs from about 16 weeks' gestation onward. These pathologic changes may have the effect of curtailing the increased blood supply required by the fetoplacental unit in the later stages of pregnancy, and correlate with decreased uteroplacental blood flow seen in most cases of preeclampsia.

The hyperuricemia of preeclampsia has been variably suggested to be associated with lactic acidosis, altered renal function, or oxidative stress. The currently favoured concept is that, increased circulating uric acid is secondary to reduced renal urate clearance, as can be seen with hypovolemia. Uric acid is the end product of purine catabolism catalysed by the enzyme xanthine oxidase/dehydrogenase. This bifunctional enzyme, in its dehydrogenase form, produces uric acid and reduced nicotinamide-adenine dinucleotide and, in the oxidase form, produces uric acid and superoxide. The enzyme is upregulated, and the expression of the oxidase form 
increased proportionally with hypoxia. Thus, increased uric acid production occurs in a setting of hypoxia, local acidosis, or increased tissue breakdown or with reduced renal function can increase oxidative stress - all of which would indicate more severe preeclampsia.

Other than reduced renal clearance, there may occurs increased placental production of UA secondary to placental ischemia and increased trophoblast shedding, leading to further purine availability for breakdown. Foetuses exposed to hypoxia (e.g. secondary to decreased placental perfusion) are found to have increased serum levels of purine metabolites. ${ }^{13}$

In preeclampsia, therefore, it is conceivable that these metabolites can cross into the maternal circulation to be degraded by maternal xanthine oxidase. These latter mechanisms might explain the relationship between raised UA levels and foetal growth retardation.

However, the increase in UA levels is too large to be attributed solely to the reduction of glomerular filtration rate; and so, there must also be decreased secretion or increased reabsorption. According to these considerations, UA could be an early marker of preeclampsia.

In this study, the level of serum CRP was higher in preeclamptic patients than the normal pregnant women $(6.8$ $\pm 3.4 \mathrm{mg} / \mathrm{L}$ versus $5.4 \pm 2.8 \mathrm{mg} / \mathrm{L}$ ) and is significant $(\mathrm{P}=0.02)$. The mean values of serum CRP levels remain higher in study group than that of control group. A significant positive correlation is observed between serum uric acid and serum CRP.

In preeclampsia the level of CRP is increased. Native CRP is synthesized in a soluble form by hepatocytes and then secreted into the circulation. The production of CRP is induced by pro-inflammatory cytokines IL-1, IL-6 and IL-17 in the liver, although extra hepatic production also contribute to systemic concentrations. Cytokines exert their biological effects on CRP, by signalling through their receptors on hepatic cells and activating different kinases and phosphatases, leading to the translocation of various transcription factors, on the CRP gene promoter, and the production of CRP. ${ }^{14}$ The sole determinant of the plasma concentration, is the rate of synthesis. The rise in blood CRP after tissue insult, or injury is rapid and robust. In preeclampsia, when there is endothelial cell injury, or endothelial cell dysfunction, the concentration doubles every 8 hours, and peaks at 36-50 hours, although that depends on the stimulus and its severity. In response to an inflammatory insult, CRP concentration can increase above $500 \mathrm{mg} / \mathrm{l}$ and this amounts to as much as a 1000-fold or more concentration change. ${ }^{15,16}$ But in case of preeclampsia, accompanied by superimposed infection, level of CRP increment is acutely higher.

There is now, clear appreciation for the role of cell adhesion molecules, angiogenic proteins, and activation of the inflammatory system in the pathogenesis of microvascular dysfunction in patients with preeclampsia. ${ }^{17}$ This provides a clear evidence for an exaggerated inflammatory response (abnormal cytokine production and neutrophil activation) in women with the clinical findings of preeclampsia. ${ }^{18,19}$

In study group, there are 21 patients, whose CRP and uric acid levels were above the upper limit of the normal range (CRP $>8 \mathrm{mg} / \mathrm{L}$ and uric acid $>6 \mathrm{mg} \%$ ) at around 30 to 34 weeks of gestation. These patients had progressed to severe pre-eclampsia and two antihypertensive drugs, for control of blood pressure were given .With early prediction, there is reduced possibility of severity of pre-eclampsia. This resulted in reduced perinatal morbidity to $33 \%$, which could have been otherwise higher, had the treatment started much later.

Of these 29 patients, increase in CRP and uric acid level was in midrange, which raised the possibility of mild severity of pre-eclampsia. Hence, treated with single hypertensive drug for control of blood pressure. Only 2 neonates, required admission in neonatal intensive care unit with a limited morbidity. One neonate had complete recovery within 48 hours. Another one, required prolonged care, because of restricted growth. Otherwise, rest of the patients had good perinatal outcome.

There was No maternal morbidity or mortality in our study.

\section{CONCLUSIONS}

Hence, it is proposed that in initial part of third trimester, we need to filter out the patients who are likely to develop pre-eclampsia due to any high risk factor. If the values of CRP and uric acid are higher at the first testing and there is an increase on repeated test, a week later, along with high blood pressure, then anti-hypertensive medication as per the requirement, one or two drugs, to attain satisfactory blood pressure should be started. This will help to minimise or to revert the damage of hypertension, on foetal growth. Thus, improve the perinatal outcome; over and above improve the maternal outcome due to reduced risks inherent of pre-eclampsia. This result justifies, performing these tests as a screening marker, to be repeated as and when required.

All the patients in study group whose measurement of uric acid and CRP levels were high, developed preeclamsia. So it can be fairly concluded, that the observed elevations in serum uric acid level or CRP level or both, preceded the development of preeclampsia.

Hyperuricemia and increased CRP level, in pre-eclamptic patients need to be confirmed, in a designed strategy, in which uric acid and CRP level are measured before the development of preeclampsia, or early in pregnancy, in order to identify and monitor the patients," at risk of 
preeclampsia", and thus provide the best prenatal care for these women and their babies.

Funding: No funding sources Conflict of interest: None declared

Ethical approval: The study was approved by the Institutional Ethics Committee

\section{REFERENCES}

1. Parks DA, Williams TK, Beckman JS. Conversion of xanthine dehydrogenase to oxidase in ischemic rat intestine: a reevaluation. Am J Physiol. 1988;254:G768-74.

2. Tan S, Gelman S, Wheat JK, Parks DA. Circulating xanthine oxidase in human ischemia reperfusion.South Med J. 1995;88:479-82.

3. Lazzarino G, Raatikainen P, Nuutinen M, Nissinen J, Tavazzi B, Di Pierro D, et al. Myocardial release of malondialdehyde and purine compounds during coronary bypass surgery.Circulation. 1994;90:291-7.

4. White CR, Darley-Usmar V, Berrington WR, Mcadams M, Gore JZ, Thompson JA, et al. Circulating plasma xanthine oxidase contributes to vascular dysfunction in hypercholesterolemic rabbits. Proc Natl Acad Sci U S A. 1996;93:8745.

5. Powers RW, Bodnar LM, Ness RB, Cooper KM, Gallaher MJ, Frank MP, et al. Uric acid concentrations in early pregnancy among preeclamptic women with gestational hyperuricemia at delivery. Am J Obstet Gynecol. 2006;194:160.

6. Johnson RJ, Kang DH, Feig D, Kivlighn S, Kanellis $\mathrm{J}$, Watanabe $\mathrm{S}$, et al. Is there a pathogenetic role for uric acid in hypertension and cardiovascular and renal disease? Hypertension. 2003;41:1183-90.

7. Reilly RD, Russell PT. Neurohistochemical evidence supporting an absence of adrenergic and cholinergic innervation in the human placenta and umbilical cord. Anat Rec. 1977;188:277-86.

8. Kang DH, Nakagawa T, Feng L, Watanabe S, Han L, Mazzali M, et al. A role for uric acid in the progression of renal disease. J Am Soc Nephrol. 2002;13:2888-97.

9. Kang DH, Finch J, Nakagawa T, Karumanchi SA, Kanellis J. Uric acid, endothelial dysfunction and pre-eclampsia: searching for a pathogenetic link. J Hypertens. 2004;22:229-35.

10. Khosla UM, Zharikov S, Finch JL, Nakagawa T, Roncal C. Hyperuricemia induces endothelial dysfunction. Kidney Int. 2005;67:1739-42.

11. Martin AC, Brown MA. Could uric acid have a pathogenic role in preeclampsia? Nat Rev Nephrol. 2010;6:744-8.

12. Elias S, Annas GJ. Generic consent for genetic screening. N Engl J Med. 1994;330:1611.

13. Saugstad OD. Hypoxantine as measurement of hypoxia. Pediatr Res. 1975;9:158-61.

14. Ingec M, Borekci B, Kadanali S. Elevated plasma homocysteine Concentrations in severe preeclampsia and eclampsia. Tohoku J Exp Med. 2005;206:22531.

15. DiNapoli M, Elkind MSV, Godoy DA, Singh P, Papa F, Wagner AP. Role of C-reactive protein in Cerebrovascular Disease. Expert Rev Cardiovasc Ther. 2011;9(12):1565-84

16. Ridker PM. C-reactive protein: A Simple Test to Help Predict Risk of Heart Attact and Stroke. Circulation. 2003;108:81-5.

17. Kolder VEB, Gallagher J, Parsons MT: Courtordered obstetrical interventions. $\mathrm{N}$ Engl J Med. 1987;316:1192.

18. Nelson LJ, Milliken N. Compelled medical treatment of pregnant women. JAMA. 1988;259:1060.

19. Notzon FC, Placek PJ, Taffel SM. Comparisons of national caesarean-section rates. $\mathrm{N}$ Engl J Med. 1987;316:386.

Cite this article as: Kaur P, Desai DA, Taraiya A, Patel A. Association of serum uric acid and Creactive protein levels in prediction of pre-eclampsia. Int J Reprod Contracept Obstet Gynecol 2016;5:495502 . 